\title{
Genome size and ploidy of Paracoccidioides brasiliensis reveals a haploid DNA content: Flow cytometry and GP43 sequence analysis
}

\author{
A.J. Almeida ${ }^{\text {a }}$, D.R. Matute ${ }^{\text {b }}$, J.A. Carmona ${ }^{\text {a }}$, M. Martins ${ }^{\text {a }}$, I. Torres ${ }^{\text {b }}$, J.G. McEwen ${ }^{\text {b,c }}$, \\ A. Restrepo ${ }^{\text {d }}$, C. Leão ${ }^{\text {a }}$, P. Ludovico ${ }^{\text {a }}$, F. Rodrigues ${ }^{\mathrm{a}, *}$ \\ ${ }^{a}$ Life and Health Sciences Research Institute (ICVS), School of Health Sciences, University of Minho, Braga, Portugal \\ ${ }^{\mathrm{b}}$ Cellular and Immunogenetics Group, Corporación para Investigaciones Biológicas (CIB), Medellín, Colombia \\ ${ }^{\mathrm{c}}$ School of Medicine, University of Antioquia, Medellin, Colombia \\ ${ }^{\mathrm{d}}$ School of Medicine, Pontifical Bolivarian University (UBP), Medellin, Colombia
}

Received 26 April 2006; accepted 12 June 2006

\begin{abstract}
The aim of this study was to evaluate genome size and ploidy of the dimorphic pathogenic fungus Paracoccidioides brasiliensis. The cell cycle analysis of 10 P. brasiliensis isolates by flow cytometry (FCM) revealed a genome size ranging from $26.3 \pm 0.1 \mathrm{Mb}(26.9 \pm 0.1 \mathrm{fg})$ to $35.5 \pm 0.2 \mathrm{Mb}(36.3 \pm 0.2 \mathrm{fg})$ per uninucleated yeast cell. The DNA content of conidia from P. brasiliensis ATCC $60855-30.2 \pm 0.8 \mathrm{Mb}$ $(30.9 \pm 0.8 \mathrm{fg})$ - showed no significant differences with the yeast form, possibly excluding the occurrence of ploidy shift during morphogenesis. The ploidy of several P. brasiliensis isolates was assessed by comparing genome sizing by FCM with the previously described average haploid size obtained from electrophoretic karyotyping. The analysis of intra-individual variability of a highly polymorphic $P$. brasiliensis gene, GP43, indicated that only one allele seems to be present. Overall, the results showed that all analysed isolates presented a haploid, or at least aneuploid, DNA content and no association was detected between genome size/ploidy and the clinical-epidemiological features of the studied isolates. This work provides new knowledge on P. brasiliensis genetics/genomics, important for future research in basic cellular/molecular mechanisms and for the development/design of molecular techniques in this fungus.
\end{abstract}

(c) 2006 Elsevier Inc. All rights reserved.

Keywords: Paracoccidioides brasiliensis; DNA content; Genome size; Ploidy

\section{Introduction}

The thermodimorphic fungus Paracoccidioides brasiliensis is the causative agent of paracoccidioidomycosis, a systemic mycosis geographically restricted to Central and South America (Restrepo and Tobón, 2005). At environmental temperatures, $P$. brasiliensis grows as mycelia and may produce conidia under specific conditions. These highly resistant structures most likely act as infectious propagules being inhaled into the lungs where the initial transformation to the distinctive pathogenic multiple budding yeast phase occurs. Both the yeast and mycelial form

\footnotetext{
${ }^{*}$ Corresponding author. Fax: +351 253604809.

E-mail address: frodrigues@ecsaude.uminho.pt (F. Rodrigues).
}

are characterized by their multinucleate nature, whereas conidia are uninucleated structures (McEwen et al., 1987; Queiroz-Telles, 1994).

Even though during the last decade molecular approaches have allowed a broader insight into $P$. brasiliensis genomic organization, definitive conclusions are far from being achieved (Felipe et al., 2005). The absence of a recognized teleomorphic stage and the fact that this fungus is relatively unamenable in what refers to basic cytogenetic analysis has contributed to the lack of substantial data regarding $P$. brasiliensis genetic composition (San-Blas et al., 2002). Consequently, several studies have employed different techniques, such as pulsed-field gel electrophoresis (PFGE) and microfluorometry (Cano et al., 1998; Feitosa et al., 2003; Montoya et al., 1999; Montoya et al., 1997), identifying four or five chromosomes - with $2-10 \mathrm{Mb}$-in 
both clinical and environmental isolates. Additionally, the existence of chromosomal polymorphism, a characteristic previously reported in other pathogenic fungi, has also been reported (Pan and Cole, 1992; Perfect et al., 1989; Thrash-Bingham and Gorman, 1992). The different sizes of chromosomal DNA molecules separated by PFGE allowed the estimation of $P$. brasiliensis genome size as $23-31 \mathrm{Mb}$ (Cano et al., 1998; Feitosa et al., 2003; Montoya et al., 1999; Montoya et al., 1997). However, results regarding microfluorometric analysis revealed that some of these isolates presented twice the genome content $(46-61 \mathrm{Mb})$ suggesting that the nuclei of $P$. brasiliensis yeast cells could be diploid, although without discarding the possibility of haploid or even aneuploid isolates (Cano et al., 1998; Feitosa et al., 2003). These studies, though reporting important information on $P$. brasiliensis genome size and ploidy, have not fully clarified these issues. On one hand, the determination by PFGE of genome size in a microorganism whose ploidy is still unknown may lead to erroneous conclusions due to limitations when separating homologous chromosomes (Torres-Guerrero, 1999). Moreover, inferring cellular ploidy on the basis of nuclear DNA content that varies along the different phases of the cell cycle may also result in incorrect assessments (Feitosa et al., 2003).

In the present work a flow cytometry $(\mathrm{FCM})$ protocol (Almeida et al., 2006) was applied to determine the genome size per uninucleated $P$. brasiliensis yeast cell and conidia. The ploidy state of several isolates was also assessed by comparing data from genome sizing by FCM with the previously described electrophoretic karyotype (Feitosa et al., 2003; Montoya et al., 1997; Montoya et al., 1999). Additionally, we evaluated the intra-individual variability of the highly polymorphic $P$. brasiliensis gene (GP43) that encodes the main antigenic component, an exocellular glycoprotein of $43 \mathrm{kDa}$ (Cisalpino et al., 1996; Morais et al., 2000), further supporting our analysis of $P$. brasiliensis ploidy state.

\section{Materials and methods}

\subsection{Microorganisms and culture media}

Paracoccidioides brasiliensis clinical and environmental isolates are listed in Table 1 and were provided by the Corporación para Investigaciones Biológicas' (Medellín, Colombia) culture collection. Yeast cells were maintained at $36^{\circ} \mathrm{C}$ by periodic subculturing in slanted tubes with brain heart infusion (BHI) solid media $(1.5 \% \mathrm{wt} / \mathrm{vol}$ agar) supplemented with $1 \%$ glucose. For subsequent assays, yeast cells were cultured in the modified synthetic McVeigh Morton (MMcM) (Restrepo and Jimenez, 1980) liquid medium at $36^{\circ} \mathrm{C}$ with aeration on a mechanical shaker (200 rpm). Stock mycelial culture was routinely grown in slanted tubes with modified $\mathrm{MMcM}$ solid medium at $18^{\circ} \mathrm{C}$. $P$. brasiliensis conidia from strain ATCC 60855 were collected and dislodged in accordance with a previously described technique (Restrepo et al., 1986).
Table 1

Paracoccidioides brasiliensis isolates analyzed during this study

\begin{tabular}{|c|c|c|c|}
\hline $\begin{array}{l}\text { Isolate } \\
\text { identification }\end{array}$ & $\begin{array}{l}\text { Country of } \\
\text { isolation }\end{array}$ & Source & Citation \\
\hline 18 & Brazil & Chronic PCM & Teixeira et al. (1987) \\
\hline ATCC 32069 & Brazil & Chronic PCM & $\begin{array}{l}\text { Restrepo-Moreno and } \\
\text { Schneidau Jr. (1967) }\end{array}$ \\
\hline Ibiá & Brazil & Soil & Silva-Vergara et al. (1998) \\
\hline $\mathrm{T} 10 \mathrm{~B} 1$ & Brazil & Armadillo & Hebeler-Barbosa et al. (2003) \\
\hline ATCC 60855 & Colombia & Chronic PCM & Gomez et al. (2001) \\
\hline 11762 & Colombia & Chronic PCM & Montoya et al. (1997) \\
\hline 29068 & Colombia & Chronic PCM & Montoya et al. (1997) \\
\hline 30878 & Colombia & Chronic PCM & Montoya et al. (1997) \\
\hline Penguin & Uruguay & Penguin & Gezuele (1989) \\
\hline 300 & Venezuela & Soil & de Albornoz (1971) \\
\hline
\end{tabular}

Saccharomyces cerevisiae haploid strain BY4742, Euro-

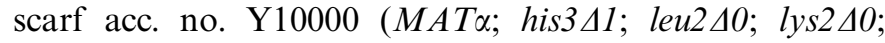
ura3 $\triangle 0$ ) and diploid strain BY4743, Euroscarf acc. no.

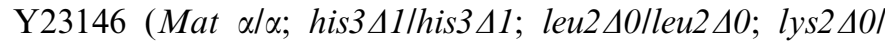
LYS2; MET15/met15 00; ura3 $40 /$ ura3 40 ; YBR011c::kanMX4/YBR011c). Both strains were grown for experimental procedures in YEPD liquid medium at $26^{\circ} \mathrm{C}$ on a mechanical shaker (160 rpm).

\subsection{Cell cycle analysis and estimation of genome size}

P. brasiliensis yeast cells of all isolates were grown in $\mathrm{MMcM}$ batch culture to the stationary phase of growth. Yeast cells and conidia suspensions were harvested by centrifugation $\left(3000 \mathrm{~g}\right.$ for $5 \mathrm{~min}$ at $\left.4{ }^{\circ} \mathrm{C}\right)$ and fixed overnight with $70 \%$ ethanol (vol $/ \mathrm{vol})$ at $4{ }^{\circ} \mathrm{C}$. Prior to sample treatment, conidia suspensions were additionally washed with $1 \%$ Tween ${ }^{\circledR} 80$ (vol/vol) and subjected to sonication (four ultrasound pulses at $40 \mathrm{~W}$ for $2 \mathrm{~s}$, with an interval of 1-2 $s$ between pulses) for removal of clumps and excessive debris, a consequence of the method applied to dislodge and collect conidia (Restrepo et al., 1986). Cell samples were collected and subjected to cell cycle analysis by flow cytometry (FCM) as previously described (Almeida et al., 2006). S. cerevisiae haploid and diploid strains were grown in YEPD liquid medium to mid-log phase or under nutrient starvation conditions and cell samples were collected and subjected to cell cycle analysis as described by Fortuna and co-workers (Fortuna et al., 2000).

The genome size estimated by FCM analysis was converted to mass of DNA using the formula reported by Dolezel and co-workers: genome size (bp) = $\left(0.978 \times 10^{9}\right) \times$ DNA content $(\mathrm{pg})($ Dolezel et al., 2003) .

\subsection{Flow cytometry}

All FCM experiments were performed on an EPICS XLMCL (Beckman-Coulter Corporation, Hialeah, Fl, USA) flow cytometer equipped with an argon-ion laser emitting a $488 \mathrm{~nm}$ beam at $15 \mathrm{~mW}$. A minimum of 30,000 cells per sample were acquired at low flow rate and an acquisition 
protocol was defined to measure forward scatter (FS LOG) and side scatter (SS LOG) on a four-decade logarithmic scale and green fluorescence (FL1) on a linear scale. Offline data were analyzed with the Multigraph software included in the system II acquisition software for the EPICS XL/XLMCL version 1.0 and the Windows Multiple Document Interface for Flow Cytometry 2.8 (WinMDI 2.8).

\subsection{Microscopic count methods and epifluorescence microscopy analysis}

Direct microscopic counts of $P$. brasiliensis yeast cells and conidia suspensions were carried out using bright-field microscopy and Neubauer counting chamber procedures. Epifluorescence microscopy was performed on a Zeiss Axioskop (Carl Zeiss, Oberkochen, Germany) epifluorescence microscope fitted with $10 \times$ eyepieces and $40 x$ and $100 \times$ (oil immersion) objectives and equipped with a Carl Zeiss AxioCam (HR/MR). Due to lower sensitivity of this technique comparatively to FCM, SYBR Green I (Molecular Probes, Eugene, Or, USA) cell staining of conidia was carried out with a final concentration of $80 \times$.

\subsection{PCR amplification, cloning and sequencing}

A fragment of $521 \mathrm{bp}$ from the GP43 locus, specifically exon 2, was obtained by PCR amplification of genomic DNA from eight randomly selected clones of $P$. brasiliensis 18, 300, ATCC 32069, Ibiá and T10B1. Total DNA was extracted from the yeast culture of each isolate with protocols using glass beads (van Burik et al., 1998) or maceration of frozen cells (Morais et al., 2000). The following primers were used: 5' CCAGGAGGCGTGCAGGTGTCCC 3' and $5^{\prime}$ GCCCCCTCCGTCTTCCATGTCC 3'. PCR was conducted in a $25 \mu \mathrm{l}$ reaction volume $(2.5 \mu 1$ of $10 \times$ PCR buffer, $1.5 \mu \mathrm{l}$ of $\mathrm{MgCl}_{2}, 2.5 \mu \mathrm{l}$ of $25 \mu \mathrm{M}$ dNTP, $0.5 \mu \mathrm{l}$ of each $10 \mu \mathrm{M}$ primer, $0.5 \mu \mathrm{l}$ of $0.5 \mathrm{U}$ PfuTurbo $\odot$ DNA Polymerase (Stratagene, Cedar Creek, TX. USA), $250 \mathrm{ng}$ of DNA template, and $18.75 \mu \mathrm{l}$ of sterile distilled water). The reactions were carried out for 1 cycle of $5 \mathrm{~min}$ at $95^{\circ} \mathrm{C}$ followed by 35 cycles of $30 \mathrm{~s}$ at $95^{\circ} \mathrm{C}$ for denaturation, $1 \mathrm{~min}$ at $51.5^{\circ} \mathrm{C}$ for annealing, and $1 \mathrm{~min}$ at $72^{\circ} \mathrm{C}$ for extension followed by 1 cycle of $5 \mathrm{~min}$ at $72^{\circ} \mathrm{C}$. The PCR product was separated by electrophoresis on a $1.5 \%$ agarose gel and the band was excised and purified using the QIAquick gel purification kit (Qiagen, Valencia, CA, USA). Purified PCR products were cloned with TOPO TA Cloning $\odot$ Kit for sequencing (Invitrogen, Carlsbad, CA, USA) following the manufacturer's protocol. Recombinant plasmid DNA was isolated with QIAprep@ 96 Turbo Miniprep Kit (Qiagen). DNA sequencing was performed with BigDye $^{\mathrm{TM}}$ Terminator Cycle Sequencing Kit v3.0 (Applied Biosystems, Foster City, CA, USA) and run on an Applied Biosystems ABI3100 automated DNA sequencer. Each purified PCR fragment was sequenced in both directions to ensure accuracy. Sequence data collected from both strands were aligned manually and examined with Sequence Navigator v. 1.0.1 (Applied Biosystems). The sequences obtained during this study have been deposited in the GenBank database under the numbers DQ364074-DQ364113.

\subsection{Statistics}

Data are reported as the mean \pm standard deviation (SD) of at least three independent assays. Mann-Whitney test regarding the genome size of $P$. brasiliensis strain ATCC 60855 conidia and yeast cells was performed using GraphPad Prism Software version 4.00 for Windows (San Diego, CA, USA).

\section{Results}

\subsection{Genome size of Paracoccidioides brasiliensis yeast form}

Aiming to determine $P$. brasiliensis genome size, a flow cytometry (FCM) protocol for cell cycle profile analysis (Almeida et al., 2006) was applied to 10 different clinical and environmental isolates (Table 1). As expected from our previous studies, this technique discriminates various cellular subpopulations with different DNA content, namely $R_{1}$, $R_{2}$ and $R_{3}$ (Fig. 1A exemplifies the case of $P$. brasiliensis 29068). All tested isolates presented half-peak coefficient of variation (HPCV) of $R_{1}$ lower than 7\% (data not shown), indicating high resolution DNA measurements and establishing a direct correlation between mean green fluorescence intensity and the amount of DNA in each cell (Rodrigues et al., 2003). As references for direct DNA estimation, we used both $S$. cerevisiae haploid and diploid strains, isogenic to the previously sequenced yeast S288C with a haploid genome of $13.5 \pm 2.5 \mathrm{Mb}$ (Goffeau et al., 1996). A concurrent cell cycle analysis of $S$. cerevisiae haploid and diploid strains revealed three distinct peaks (Fig. 1B-I), corresponding to $1 n, 2 n$ and $4 n$ DNA contents, where the mean green fluorescence intensity of each peak was directly correlated to the amount of DNA $(\mathrm{Mb})$ of its corresponding cell subpopulation (Fig. 1B-II, $r^{2}>0.999$ ). The analysis of different ratios of mixed cell populations of each $P$. brasiliensis isolate and $S$. cerevisiae haploid strain was then used to determine single-cell DNA content (Fig. 1C). The genome size of each $P$. brasiliensis isolate was estimated in accordance with $R_{1}$ subpopulation of the cell cycle profile, previously characterized as being composed by uninucleated cells (Almeida et al., 2006). The average amount of DNA per cell was determined as ranging between $26.3 \pm 0.1$ and $35.5 \pm 0.2 \mathrm{Mb}$ (Table 2) and was converted to mass of DNA content (Dolezel et al., 2003), varying from $26.9 \pm 0.1$ to $36.3 \pm 0.2 \mathrm{fg} /$ yeast uninucleated cell (Table 2).

\subsection{Genome content of P. brasiliensis conidia}

P. brasiliensis conidia are uninucleated structures generally accepted to be the natural infectious form of this 

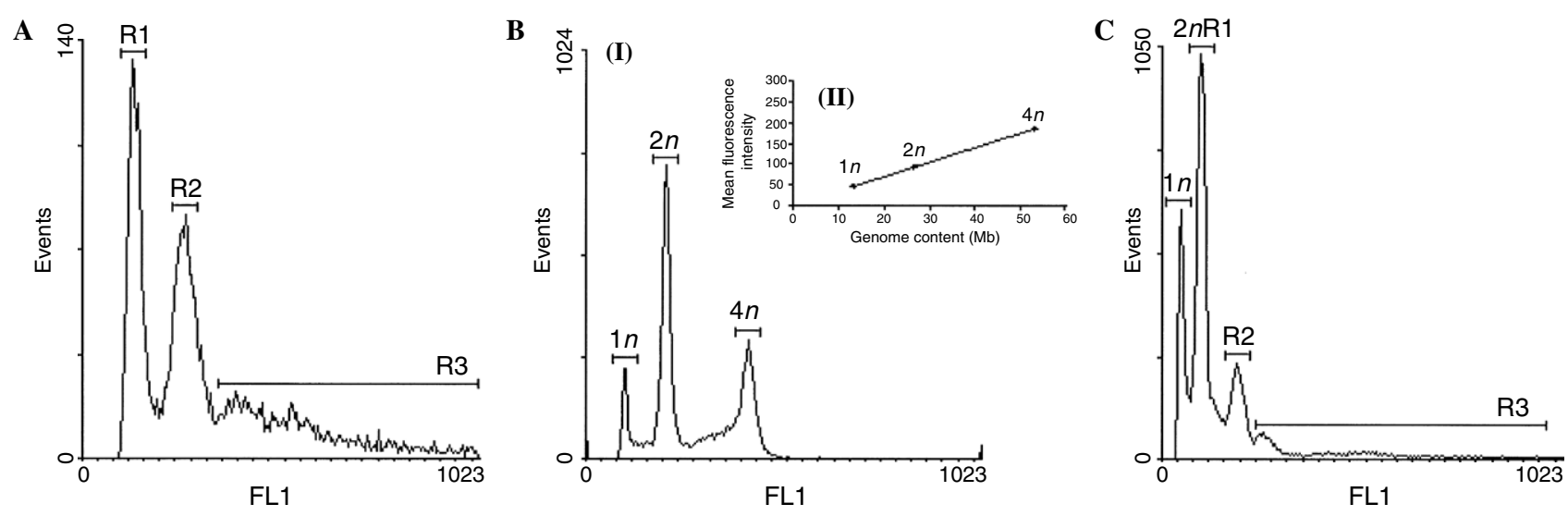

Fig. 1. Representative cell cycle analysis histograms of: (A) P. brasiliensis 29068 yeast cells grown in MMcM medium to the stationary phase of growth (discrimination of subpopulations $R_{1}, R_{2}$ and $R_{3}$ ); (B) (I) mixed cell populations of $S$. cerevisiae haploid and diploid strains grown to the exponential phase of growth in YEPD medium and (II) graph shows typical standard curve relating mean fluorescence intensity of the peaks $1 n, 2 n$ and $4 n$ of $S$. cerevisiae strains and the theoretical amount of DNA per cell; and (C) mixed cell populations of P. brasiliensis 29068 yeast cells and $S$. cerevisiae haploid strain.

Table 2

Genome size $(\mathrm{Mb})$ and DNA content ( $\mathrm{fg})$ per uninucleated cell of $P$. brasiliensis isolates estimated by flow cytometry of SYBR Green I-stained cells

\begin{tabular}{lrrl}
\hline Microorganisms & MFI $\pm \mathrm{SD}^{\mathrm{a}}$ & $\begin{array}{l}\text { Genome size } \pm \\
\mathrm{SD}(\mathrm{Mb})\end{array}$ & $\begin{array}{l}\text { DNA content } \pm \\
\mathrm{SD}(\mathrm{fg})^{\mathrm{c}}\end{array}$ \\
\hline S. cerevisiae & & & \\
BY4742 & $48.2 \pm 1.5$ & $13.25 \pm 0.4^{\mathrm{b}}$ & $13.5 \pm 0.4$ \\
BY4743 & $94.6 \pm 2.5$ & $26.5 \pm 0.7^{\mathrm{b}}$ & $27.1 \pm 0.7$ \\
P. brasiliensis & & & \\
18 & $95.7 \pm 0.3$ & $26.3 \pm 0.1$ & $26.9 \pm 0.1$ \\
ATCC 32069 & $119.2 \pm 3.8$ & $32.8 \pm 1.0$ & $33.5 \pm 1.2$ \\
Ibiá & $108.9 \pm 0.6$ & $29.9 \pm 0.2$ & $30.6 \pm 0.2$ \\
T10B1 & $129.1 \pm 0.7$ & $35.5 \pm 0.2$ & $36.3 \pm 0.2$ \\
ATCC 60855 & & & \\
$\quad$ Yeast & $113.9 \pm 1.9$ & $31.3 \pm 0.5$ & $32.0 \pm 0.5^{\mathrm{d}}$ \\
$\quad$ Conidia & $109.9 \pm 2.8$ & $30.2 \pm 0.8$ & $30.9 \pm 0.8^{\mathrm{d}}$ \\
11762 & $126.5 \pm 2.0$ & $34.8 \pm 0.5$ & $35.5 \pm 0.6$ \\
29068 & $116.4 \pm 3.1$ & $32.0 \pm 0.9$ & $32.7 \pm 0.9$ \\
30878 & $117.1 \pm 4.2$ & $32.3 \pm 1.2$ & $33.0 \pm 1.2$ \\
Penguin & $112.2 \pm 5.6$ & $30.9 \pm 1.5$ & $31.5 \pm 1.6$ \\
300 & $128.3 \pm 1.4$ & $35.3 \pm 0.4$ & $36.1 \pm 0.4$ \\
\hline \multicolumn{2}{c}{ a } & &
\end{tabular}

${ }^{a}$ Mean fluorescence intensity (MFI) of cells in $G_{0} / G_{1}$ phases ( $S$. cerevisiae strains) or $R_{1}$ subpopulation ( $P$. brasiliensis isolates) of the cell cycle profile.

b Theoretical genome size of $S$. cerevisiae haploid and diploid strains (Goffeau et al., 1996).

c DNA content, in fentograms, calculated accordingly with Dolezel and co-workers (Dolezel et al., 2003).

${ }^{\mathrm{d}}$ No significant differences detected between $P$. brasiliensis strain ATCC 60855 conidia and yeast form $(P>0.05)$.

dimorphic fungus and its morphological switch to the pathogenic yeast leads to the appearance of multinucleated cells, raising questions on the occurrence of ploidy shifts during this transition (McEwen et al., 1987; Aristizabal et al., 1998). In this sense, we have adapted the protocol for cell cycle profile analysis of yeast cells (Almeida et al., 2006) to determine the genome size of these structures in $P$. brasiliensis ATCC 60855. Epifluorescence microscopy analysis revealed specific and homogenous nuclear staining (Fig. 2A), confirming the uninucleated feature of P. brasili- ensis conidia. Moreover, the treatment of SYBR Green Istained conidia with DNase I led to the loss of green fluorescence, indicating specific DNA labeling (data not shown). FCM evaluation indicated high peak resolution with a HPCV lower than 7\% (data not shown), allowing the correct estimation of the DNA content per conidia (Fig. 2B-I). By mixed cell staining with S. cerevisiae haploid reference strain (Fig. 2B-II), the DNA content per conidia was determined as $30.2 \pm 0.8 \mathrm{Mb}$, corresponding to a mass of DNA of $30.9 \pm 0.8 \mathrm{fg}$ per conidia (Table 2). No significant differences were detected between the DNA content of $P$. brasiliensis pathogenic yeast phase and the infectious propagules $(P>0.05)$.

\subsection{P. brasiliensis ploidy}

Ploidy level is generally defined by the number of copies of each individual set of chromosomes per nucleus, thus an organism carrying one or two sets of nuclear chromosomes is classified as haploid or diploid, respectively, whereas aneuploidy is characterized by a non-integer ploidy number (Zeyl, 2004). In this sense, we have compared the DNA content of uninucleated yeast cells determined by FCM (Table 2 ), with the average haploid genome size estimated by pulsed field gel electrophoresis (PFGE) (Feitosa et al., 2003; Montoya et al., 1997; Montoya et al., 1999) of seven clinical and environmental $P$. brasiliensis isolates, thus establishing a ploidy ratio that infers the ploidy state of the studied organism (Carr and Shearer, 1998). P. brasiliensis 29068, Ibiá and Penguin presented a ploidy ratio of approximately 1.0 , compatible with a haploid DNA content (Table 3). In contrast, for P. brasiliensis, 18, 11762, 30878 and ATCC 32069 the ploidy ratio was slightly higher (1.1), indicating a haploid, or at least an aneuploid, DNA content (Table 3).

On the other hand, the cellular ploidy state can also be molecularly determined by the identification of intra-individual variability in genes that are known to be single copy and highly polymorphic. Therefore, the gene encoding the P. brasiliensis glycoprotein gp43 was evaluated assuming 


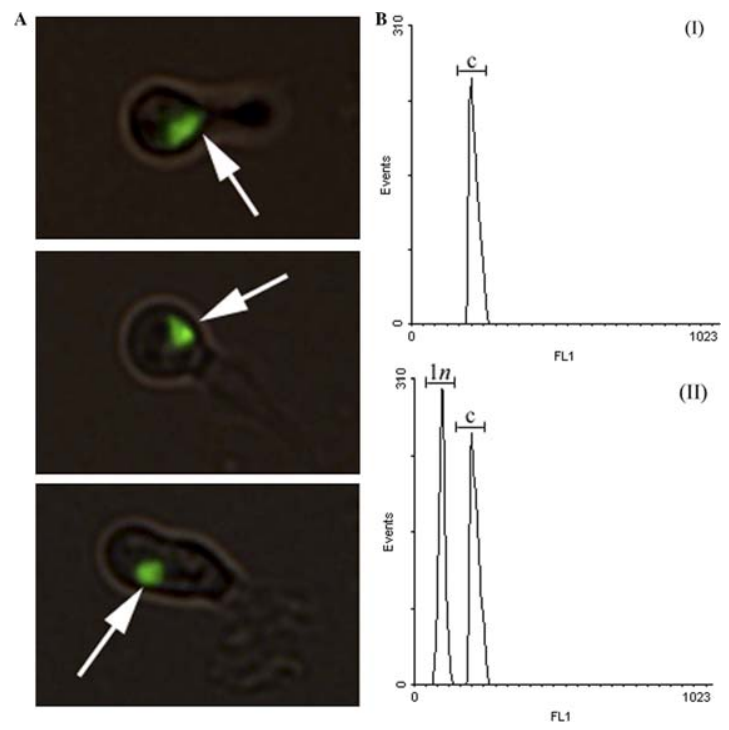

Fig. 2. Paracoccidioides brasiliensis conidia, strain ATCC 60855, submitted to cell cycle analysis. (A) Epifluorescence microscopy analysis (overlap of bright field and green fluorescence); white arrows indicate SYBR Green I nuclear staining. (B) Representative green fluorescence (FL1) histogram of (I) conidia cells (c) and (II) mixed cell populations of conidia cells (c) and $S$. cerevisiae haploid strain under nutrient starvation $(1 n)$.

Table 3

Comparison of the genome size of different $P$. brasiliensis isolates determined by flow cytometry (FCM) with data regarding the chromosomesized DNA separated by pulsed-field gel electrophoresis (PFGE) (Feitosa et al., 2003; Montoya et al., 1997; Montoya et al., 1999)

\begin{tabular}{|c|c|c|c|}
\hline $\begin{array}{l}\text { Isolate } \\
\text { identification }\end{array}$ & $\begin{array}{l}\text { Genome size } \pm \\
\mathrm{SD}(\mathrm{Mb})^{\mathrm{a}}\end{array}$ & $\begin{array}{l}\sum \text { of PFGE } \\
\text { bands }(\mathrm{Mb})^{\mathrm{b}}\end{array}$ & $\begin{array}{l}\text { Ploidy } \\
\text { ratio }^{\mathrm{c}}\end{array}$ \\
\hline 18 & $26.3 \pm 0.1$ & 23.3 & 1.1 \\
\hline ATCC 32069 & $32.8 \pm 1.0$ & 28.9 & 1.1 \\
\hline Ibiá & $29.9 \pm 0.2$ & 29.7 & 1.0 \\
\hline 11762 & $34.8 \pm 0.5$ & 33.0 & 1.1 \\
\hline 29068 & $32.0 \pm 0.9$ & 30.5 & 1.0 \\
\hline 30878 & $32.3 \pm 1.2$ & 30.5 & 1.1 \\
\hline Penguin & $30.9 \pm 1.5$ & 29.7 & 1.0 \\
\hline
\end{tabular}

a Genome size, in megabases, of $P$. brasiliensis isolates estimated by FCM.

b Sum of $P$. brasiliensis chromosomal bands separated by PFGE, in megabases (Feitosa et al., 2003; Montoya et al., 1997; Montoya et al., 1999).

${ }^{c}$ Ratio of the genome size estimated by FCM and $\sum$ of PFGE bands.

that if the isolates were diploid or polyploid, certain variability would be detected within these sequences (Matute et al., 2006; Morais et al., 2000). Following this line of thought, we sequenced eight randomly selected clones containing the exon 2 of GP43 gene for each $P$. brasiliensis isolate, namely 18, 300, ATCC 32069, Ibiá and T10B1 (GenBank database numbers DQ364074- DQ364113). To infer ploidy, we calculated the recovery probability for only one of the alleles under the assumption that all the alleles present the same frequency. Therefore, if $P$. brasiliensis cells were haploid the recovery probability would be equal to the allelic frequency (1.00) since only one allele would exist. In the case of being diploid, the allelic frequency would be 0.50 and the probability of not recovering one of the alleles, in spite of their existence, 0.50 to the 8 th power $\left(3.90 \times 10^{-3}\right)$.
If $P$. brasiliensis were triploid, then the allelic frequency would be 0.33 and the recovery probability would be $1.52 \times 10^{-4}$. According to these data, only one allele seems to exist within each studied isolate indicating that they are most likely haploid.

\section{Discussion}

The main goal of our work was to obtain new insights regarding Paracoccidioides brasiliensis genome size and ploidy. We studied 10 P. brasiliensis isolates, originally isolated from both clinical and environmental specimens, from four distinct endemic areas of paracoccidioidomycosis (Brazil, Colombia, Uruguay and Venezuela) (Restrepo and Tobón, 2005). Furthermore, representatives of all three recently identified species (S1, PS2 and PS3) are present within the studied isolates (Matute et al., 2006).

Recently, our group applied a flow cytometry (FCM) protocol to characterize the cellular morphology and nuclei content of the various subpopulations discriminated during cell cycle profile analysis of $P$. brasiliensis yeast cells (Almeida et al., 2006). This technique, besides being less time-consuming and analyzing larger samples, characterizes the various subpopulations discriminated during cell cycle analysis, being therefore not only complementary to other DNA content quantification methods but also further informative concerning genome size and ploidy (Dolezel and Bartos, 2005). Thus, we were able to estimate the DNA content in accordance with the FCM analysis of uninucleated cells, specifically subpopulation $R_{1}$ (Fig. 1A). Our results indicate that $P$. brasiliensis uninucleated yeast cells present a genome size similar to those previously determined by the summation of the chromosomes length (23$31 \mathrm{Mb}$ ), with a low intraspecific variability (Table 2), as described elsewhere (Cano et al., 1998; Feitosa et al., 2003; Montoya et al., 1999; Montoya et al., 1997). Moreover, we estimated the DNA content of $P$. brasiliensis conidia, strain ATCC 60855 , and compared it with the yeast form results $(30.9 \pm 0.8$ and $32.0 \pm 0.5$, respectively) $(P>0.05)$. These data seem to exclude the occurrence of ploidy shift during morphogenesis from the infectious propagules to its pathogenic yeast form, an important feature of $P$. brasiliensis virulence traits; however, additional studies must be conducted to completely rule out this hypothesis

Taking under consideration that ploidy is an essential genetic feature that underlies significant cytological and physiological characteristics (Zeyl, 2004), the cellular ploidy level of several $P$. brasiliensis isolates was assessed. Results regarding genome sizing of seven $P$. brasiliensis isolates by FCM were used as complementary data to those obtained through electrophoretic karyotyping (Feitosa et al., 2003; Montoya et al., 1997; Montoya et al., 1999) and a ploidy ratio was defined as the DNA content per uninucleated cell per haploid genome size (Table 3). Data presented throughout this report showed that all analyzed isolates feature a ploidy ratio between 1.0 and 1.1. Although these results are nearer to a haploid DNA content, as in other pathogenic 
fungi aneuploidy must also be taken under consideration (Carr and Shearer, 1998; Feitosa et al., 2003; Lengeler et al., 2001; Torres-Guerrero, 1999). Nevertheless, the genome size estimated by FCM includes DNA external to the nucleus (e.g., mitochondrial DNA), conversely to that determined by the summation of chromosomal molecules (Hijri and Sanders, 2004). Since P. brasiliensis yeast cells are characterized by presenting an increased number of mitochondria, a slight overestimation would be expected (Queiroz-Telles, 1994). Furthermore, the ploidy state of five $P$. brasiliensis isolates, three of which included in the previous analysis-18, ATCC 32069 and Ibiá-, was inferred by evaluating the intra-individual variability of the GP43 gene, which encodes an exocelullar glycoprotein and the major antigenic component in this pathogenic fungus (Cisalpino et al., 1996). The GP43 gene was selected not only because it is highly polymorphic, particularly exon 2 , but also because it is single copy and no known paralogs have yet been reported, thus ruling out the presence of a homologous sequence derived from gene duplication within the genome (Morais et al., 2000). No intra-individual variations were detected, even though some variation was observed among different isolates, as described elsewhere (Matute et al., 2006). The results indicated that only one allele seems to be present per individual, thus pointing to a haploid DNA content of all isolates. Interestingly, $P$. brasiliensis isolates 18, ATCC 32069 and Ibiá were previously described as diploid, conflicting with our results from both approaches applied for ploidy assessment (Cano et al., 1998; Feitosa et al., 2003). In fact, data reported by Feitosa and co-workers (2003) showed that eight out of twelve isolates were diploid, whereas our results indicate that all isolates presented a haploid, or at least, an aneuploid DNA content. Nevertheless, in those studies the genome size was attained by microfluorometry of stained nuclei and as such subjected to variations in nuclei number per cell or nuclear DNA content due to uncharacterized nuclear cell cycle phase of this dimorphic pathogenic fungus. Furthermore, Morais and co-workers (2000) reported that isolate 18 possessed two genotypic forms of GP43 based on the distribution of nucleotide polymorphisms, indicating that this isolate, among others, could be diploid (13 out of 17 isolates were suggested as diploid). However, these results might also be explained by errors inherent to the applied methodology since polymorphisms were detected as alterations in only one nucleotide and always at distinct sites within the same isolate (Morais et al., 2000). In addition, while these authors analyze only two PCR GP43 fragments we evaluated eight fragments from each single isolate further validating our findings. Overall, our results clearly show that a significant amount of $P$. brasiliensis cells in batch culture present a haploid, or at least aneuploid, DNA content. However, one should take into account that our analysis of genome size and ploidy was based on the uninucleated cell subpopulation presenting the lowest DNA content $\left(R_{1}\right)$, within a total population of 30,000 cells. In this sense, it is not possible to discard the presence of a small number of cells with distinct ploidy levels within the total cell population, a phenomenon that has already been reported for the pathogenic fungus Cryptococcus neoformans (Hata et al., 2000).

This study provides information that addresses fundamental questions of $P$. brasiliensis biology, namely genome size and ploidy, an important asset for the development/ design of molecular techniques (e.g., gene disruption and/or over-expression) and the future genetic manipulation of this human dimorphic pathogen. As stated beforehand, we analyzed isolates that are greatly diverse not only in the source of origin (clinical and environmental isolates) and country of isolation, but also in respect to distinctly recognized species of this pathogenic fungus (Matute et al., 2006). Even though no association was detected between genome size/ploidy and the clinical-epidemiological features of the studied isolates, one cannot discard the importance of these parameters in the regulation of basic cellular and molecular mechanisms, particularly $P$. brasiliensis pathogenesis. Nonetheless, a wide range analysis of a higher number of isolates concerning the incidence and phenotype of the disease is necessary to evaluate possible differences among virulence and genome size and/or ploidy state.

\section{Acknowledgments}

We are grateful for technical assistance provided by Orville Hernandez during isolation of $P$. brasiliensis conidia and Teresa E. Pawlowska during the cloning of the PCR products. Agostinho J. Almeida was financially supported by a fellowship from Fundação para a Ciência e Tecnologia (FCT), Portugal (contract SFRH/BD/8655/ 2002). This work was supported by the FCT research Grant POCTI/ESP/45327/2002.

\section{References}

Almeida, A.J., Martins, M., Carmona, J.A., Cano, L.E., Restrepo, A., Leao, C., Rodrigues, F., 2006. New insights into the cell cycle profile of Paracoccidioides brasiliensis. Fungal. Genet. Biol. 43, 401-409.

Aristizabal, B.H., Clemons, K.V., Stevens, D.A., Restrepo, A., 1998. Morphological transition of Paracoccidioides brasiliensis conidia to yeast cells: in vivo inhibition in females. Infect. Immun. 66, 55875591.

Cano, M.I., Cisalpino, P.S., Galindo, I., Ramirez, J.L., Mortara, R.A., da Silveira, J.F., 1998. Electrophoretic karyotypes and genome sizing of the pathogenic fungus Paracoccidioides brasiliensis. J. Clin. Microbiol. $36,742-747$

Carr, J., Shearer Jr., G., 1998. Genome size, complexity, and ploidy of the pathogenic fungus Histoplasma capsulatum. J. Bacteriol. 180, 6697-6703.

Cisalpino, P.S., Puccia, R., Yamauchi, L.M., Cano, M.I., da Silveira, J.F., Travassos, L.R., 1996. Cloning, characterization, and epitope expression of the major diagnostic antigen of Paracoccidioides brasiliensis. J. Biol. Chem. 271, 4553-4560.

de Albornoz, M.B., 1971. Isolation of Paracoccidioides brasiliensis from rural soil in Venezuela. Sabouraudia 9, 248-253.

Dolezel, J., Bartos, J., 2005. Plant DNA flow cytometry and estimation of nuclear genome size. Ann. Bot. (Lond) 95, 99-110.

Dolezel, J., Bartos, J., Voglmayr, H., Greilhuber, J., 2003. Nuclear DNA content and genome size of trout and human. Cytometry A 51, $127-128$. 
Feitosa, L.S., Cisalpino, P.S., dos Santos, M.R., Mortara, R.A., Barros, T.F., Morais, F.V., et al., 2003. Chromosomal polymorphism, syntenic relationships, and ploidy in the pathogenic fungus Paracoccidioides brasiliensis. Fungal Genet. Biol. 39, 60-69.

Felipe, M.S., Torres, F.A., Maranhao, A.Q., Silva-Pereira, I., Pocas-Fonseca, M.J., Campos, E.G., et al., 2005. Functional genome of the human pathogenic fungus Paracoccidioides brasiliensis. FEMS Immunol. Med. Microbiol. 45, 369-381.

Fortuna, M., Sousa, M.J., Corte-Real, M., Leao, C., Salvador, A., Sansonetty, F., 2000. Cell cycle analysis of yeast. In: Current Protocols in Flow Cytometry. John Wiley \& Sons, Inc., pp. 11.13.1-11.13.9.

Gezuele, E. Aislamiento de Paracoccidioides brasiliensis sp de heces de pinguinode en la Antartida. Encuentro Internacional sobre Paracocidioidomicosis. 1989. Caracas. (Conference Proceeding).

Goffeau, A., Barrell, B.G., Bussey, H., Davis, R.W., Dujon, B., Feldmann, H., et al., 1996. Life with 6000 genes. Science 274, 546. $563-$ $546,567$.

Gomez, B.L., Nosanchuk, J.D., Diez, S., Youngchim, S., Aisen, P., Cano, L.E., et al., 2001. Detection of melanin-like pigments in the dimorphic fungal pathogen Paracoccidioides brasiliensis in vitro and during infection. Infect. Immun. 69, 5760-5767.

Hata, K., Ohkusu, M., Aoki, S., Ito-Kuwa, S., Pienthaweechai, K., Takeo, K., 2000. Cells of different ploidy are often present together in Cryptococcus neoformans strains. Nippon Ishinkin Gakkai Zasshi 41, 161167.

Hebeler-Barbosa, F., Montenegro, M.R., Bagagli, E., 2003. Virulence profiles of ten Paracoccidioides brasiliensis isolates obtained from armadillos (Dasypus novemcinctus). Med. Mycol. 41, 89-96.

Hijri, M., Sanders, I.R., 2004. The arbuscular mycorrhizal fungus Glomus intraradices is haploid and has a small genome size in the lower limit of eukaryotes. Fungal Genet. Biol. 41, 253-261.

Lengeler, K.B., Cox, G.M., Heitman, J., 2001. Serotype AD strains of Cryptococcus neoformans are diploid or aneuploid and are heterozygous at the mating-type locus. Infect. Immun. 69, 115-122.

Matute, D.R., McEwen, J.G., Puccia, R., Montes, B.A., San-Blas, G., Bagagli, E., et al., 2006. Cryptic speciation and recombination in the fungus Paracoccidioides brasiliensis as revealed by gene genealogies. Mol. Biol. Evol. 23, 65-73.

McEwen, J.G., Restrepo, B.I., Salazar, M.E., Restrepo, A., 1987. Nuclear staining of Paracoccidioides brasiliensis conidia. J. Med. Vet. Mycol. 25, 343-345.

Montoya, A.E., Alvarez, A.L., Moreno, M.N., Restrepo, A., McEwen, J.G., 1999. Electrophoretic karyotype of environmental isolates of Paracoccidioides brasiliensis. Med. Mycol. 37, 219-222.

Montoya, A.E., Moreno, M.N., Restrepo, A., McEwen, J.G., 1997. Electrophoretic karyotype of clinical isolates of Paracoccidioides brasiliensis. Fungal Genet. Biol. 21, 223-227.

Morais, F.V., Barros, T.F., Fukada, M.K., Cisalpino, P.S., Puccia, R., 2000. Polymorphism in the gene coding for the immunodominant antigen gp43 from the pathogenic fungus Paracoccidioides brasiliensis. J. Clin. Microbiol. 38, 3960-3966.

Pan, S., Cole, G.T., 1992. Electrophoretic karyotypes of clinical isolates of Coccidioides immitis. Infect. Immun. 60, 4872-4880.

Perfect, J.R., Magee, B.B., Magee, P.T., 1989. Separation of chromosomes of Cryptococcus neoformans by pulsed field gel electrophoresis. Infect. Immun. 57, 2624-2627.

Queiroz-Telles, F., 1994. Paracoccidioides brasiliensis Ultrastructural Findings. In: Franco, M., Lacaz, C.S., Restrepo-Moreno, A., Del Negro, G.M. (Eds.), CRS Press, London, pp. 27-44.

Restrepo, A., Jimenez, B.E., 1980. Growth of Paracoccidioides brasiliensis yeast phase in a chemically defined culture medium. J. Clin. Microbiol. $12,279-281$.

Restrepo, A., Salazar, M.E., Cano, L.E., Patino, M.M., 1986. A technique to collect and dislodge conidia produced by Paracoccidioides brasiliensis mycelial form. J. Med. Vet. Mycol. 24, 247-250.

Restrepo, A., Tobón, A. 2005. Paracoccidioides brasiliensis. In: Mandell, G.L., Bennett, J.E., Dollin, R. (Eds)., Principles and Practice of Infectious Diseases, Philadelphia, pp. 3062-3068.

Restrepo-Moreno, A., Schneidau Jr., J.D., 1967. Nature of the skin-reactive principle in culture filtrates prepared from Paracoccidioides brasiliensis. J. Bacteriol. 93, 1741-1748.

Rodrigues, F., Ludovico, P., Sousa, M.J., Steensma, H.Y., Corte-Real, M., Leao, C., 2003. The spoilage yeast Zygosaccharomyces bailii forms mitotic spores: a screening method for haploidization. Appl. Environ. Microbiol. 69, 649-653.

Sambrook, J., Fritsch, E.F., Maniatis, T., 1998. Molecular Cloning: A Laboratory Manual. Cold Spring Harbor Laboratory Press, New York.

San-Blas, G., Nino-Vega, G., Iturriaga, T., 2002. Paracoccidioides brasiliensis and paracoccidioidomycosis: molecular approaches to morphogenesis, diagnosis, epidemiology, taxonomy and genetics. Med. Mycol. 40, 225-242.

Silva-Vergara, M.L., Martinez, R., Chadu, A., Madeira, M., Freitas-Silva, G., Leite Maffei, C.M., 1998. Isolation of a Paracoccidioides brasiliensis strain from the soil of a coffee plantation in Ibia, State of Minas Gerais, Brazil. Med. Mycol. 36, 37-42.

Teixeira, H.C., Calich, V.L., Singer-Vermes, L.M., Imperio-Lima, M.R., Russo, M., 1987. Experimental paracoccidioidomycosis: early immunosuppression occurs in susceptible mice after infection with pathogenic fungi. Braz. J. Med. Biol. Res. 20, 587-589.

Thrash-Bingham, C., Gorman, J.A., 1992. DNA translocations contribute to chromosome length polymorphisms in Candida albicans. Curr. Genet. 22, 93-100.

Torres-Guerrero, H., 1999. Ploidy study in Sporothrix schenkii. Fungal Genet. Biol. 27, 49-54.

van Burik, J.A., Schreckhise, R.W., White, T.C., Bowden, R.A., Myerson, D., 1998. Comparison of six extraction techniques for isolation of DNA from filamentous fungi. Med. Mycol. 36, 299-303.

Zeyl, C., 2004. Experimental studies on ploidy evolution in yeast. FEMS Microbiol. Lett. 233, 187-192. 